\title{
Biology and feeding potential Episyrphus balteatus De Geer (Diptera: Syrphidae) on green apple aphid Aphis pomi De Geer (order Hemiptera: Aphididae) in Hills of Shimla, (H.P.), India
}

\section{Kumari Meena}

Received: 20.12.2019
Revised: 14.02.2020

Accepted: 11.03.2020

\begin{abstract}
In the present study three species of syrphid predators were found feeding on green apple aphid on the apple nursery plants. These species are Betasyrphus serarius (Wiedemann), Episyrphus balteatus De Geer, and Metasyrphus confrater (Wiedemann). These syrphid species belonging to Family Syrphidae of order Diptera. Observations were made on Episyrphus balteatus De Geer a syrphid predator of green apple aphid, Aphis pomi De Geer in Shimla Hills of Himachal Pradesh, India. The larval stages of Episyrphus balteatus De Geer, was found to predate upon the green apple aphid, Aphis pomi De Geer which is a serious pest of apple nursery plants in Himachal Pradesh which is the main apple growing state of India. Feeding potential of larval stages of Episyrphus balteatus De Geer was recorded during summer and autumn season. Present studies show that the larvae of this species can effectively control the populations of green apple aphid, Aphis pomi De Geer in the apple orchards and nurseries.
\end{abstract}

Key words: Feeding potential, Biology, Green apple aphid, Syrphid predator

\section{Introduction}

Green apple aphid, Aphis pomi De Geer infests apple plants throughout the year and poses a great problem to the apple growers as serious losses occur in nurseries and orchards. Big aphid colonies result in reduced yield as well as retardation in shoot growth (Hamilton et al., 1986). Aphis pomi attacks primarily the growing terminals of apple plants. Heavy infestations of green apple aphid result in curling of leaves and stunting and distorting the twigs of apple nursery and young plants. On fruit bearing trees, honeydew production adversely affects photosynthesis, quality and yield of apples (Oatman and Legner, 1961). Many predators consume nymphs and adults of green apple aphid and the potential of these predators varied from year to year and from region to region (Carrol and Hoyt, 1984). Control of aphids usually requires a more complex approach for which the basic knowledge of biology of predator species is prerequisite. Many natural enemies have been reported in association with green apple aphid, Aphis pomi De Geer from different parts of the world (Banks, 1952; Carrol and Hoyt, 1984). This

\section{Author's Address}

Department of Zoology, Govt. College Kullu, Himachal Pradesh, India 175101

E-mail.: meenakchaudhary@gmail.com insect pest has been reported to infest apple plants in Himachal Pradesh state of India. The young and nursery plants are affected the worst (Gautam and Kumari, 2004). However, there is no record available on the syrphid predators of green apple aphid in India. The present studies were undertaken to record the syrphid predators of green apple aphid occuring in Himachal Pradesh, India and to study their life history and feeding potential in this region of North western Himalayas. Such studies may prove useful for applying biological control of this aphid pest in this region where infestation of green apple aphid is very high.

\section{Material and Methods \\ Study area}

Regular field surveys of apple nurseries were conducted in two localities i.e. Mashobra locality $\left(31^{0} 1\right.$ 'N latitude, $77^{0} 1^{\prime} \mathrm{E}$ longitude and altitude 2286 $\mathrm{m}$ above sea level) of Shimla district and Ner chowk locality $\left(31^{0} 32^{\prime} \mathrm{N}\right.$ latitude, $76^{0} 54^{\prime} \mathrm{E}$ longitude and altitude $878 \mathrm{~m}$ above sea level) of Mandi district of Himachal Pradesh state of India to ascertain the syrphid predators of green apple aphid. These studies were spread over three years from 2003 to 2006 and the observations were reconfirmed in the last three years also i.e. 2015 to 
2017. The data on different developmental stages and their feeding potential were recorded from May to November covering mainly two seasons i.e. summer (May-August) and autumn (SeptemberNovember). Eggs of syrphid flies were collected from the field and after hatching, the development of the larvae was observed. The feeding potential of 10 larvae of each species was recorded. A fixed number of aphids were given to larvae and they were examined after regular intervals of time to record the feeding potential. The duration of different stages were noted down. Data was analyzed statistically using $t$ test. Hypothesis taken $\mathrm{H}_{0}$ : There is no difference of summer and Autumn season, in the total life span of Episyrphus balteatus De Geer, $\mathrm{H}_{1}$ : There is difference of summer and Autumn season, in the total life span of Episyrphus balteatus De Geer, $\mathrm{H}_{0}$ : There is no difference between summer and Autumn season, in the total number of aphids consumed in life span of Episyrphus balteatus De Geer, $\mathrm{H}_{1}$ : There is difference between summer and Autumn season, in the total number of aphids consumed life span of Episyrphus balteatus De Geer.

However, there is no record available on the syrphid predators of green apple aphid in India. Adult flies were maintained on $10 \%$ honey solution soaked in cotton along with some commonly available flowering shoots under laboratory conditions to record the adult life span.

\section{Results and Discussion}

Observations on young nursery and fruit bearing apple revealed that from May to November when the infestation rate of green apple aphid was high, the larvae of Episyrphus balteatus De Geer, was found preying on green apple aphid. This syrphid predator belonging to Family Syrphidae of order Diptera. As the infestation of green apple aphid increases on the plants, the syrphid flies start laying eggs. The number of eggs laid also depends upon the number of aphids, larger the number of aphids, more is the number of eggs laid. Syrphid flies lay eggs singly or in groups on the lower surface of the leaves. The eggs are chalk white in colour and can easily be recognized on the green surface of leaf on which they are laid. Syrphids lay eggs only during the day time. Initial instars are poor feeders and their capacity of feeding increases during subsequent instar stages. The larvae become voracious feeder in last instar stage.

\section{Episyrphus balteatus De Geer}

The eggs of Episyrphus balteatus are pale white in colour when freshly laid but turn greyish before hatching. Eggs are oval in shape. The eggs hatch in 2 days in summer (mean 2 days $\pm 0.00 \mathrm{SE}$ ) while in autumn these take from 2 to 3 days (mean 2.55 days $\pm 0.13 \mathrm{SE}$ ) days (Table 1). The larva (Figure 1) of Episyrphus balteatus appears transparent, so the black viscera are visible through the body. Larva has three instar stages. The total larval period ranges from 7 to 9 days (mean 7.90 days $\pm 0.27 \mathrm{SE}$ ) during summer and 13 to 17 days (mean 15 days \pm $0.51 \mathrm{SE}$ ) during autumn (Table 1). The full grown larva is also transparent and pupates within the final instar that forms a protective puparium. The colour of pupa varies from whitish to greyish white. The pupa is broad and round in the anterior portion and narrower in the posterior end. The duration of pupal stage ranges from 8 to 9 days (mean 8.50 days \pm $0.16 \mathrm{SE}$ ) during summer and 13 to 18 days (mean 15.30 days $\pm 0.55 \mathrm{SE}$ ) during autumn (Table 1 ).

Adult (Figure 2) of this species is very active and it is the most abundant aphidophagous syrphid fly. This fly is found throughout the spring, summer and autumn. The duration of adult Episyrphus balteatus ranges from 25 to 38 days (mean 31.10 days $\pm 1.41 \mathrm{SE}$ ) during summer and from 45 to 60 days (mean 53.20 days $\pm 1.51 \mathrm{SE}$ ) during autumn (Table 1). Duration of total life span of Episyrphus balteatus ranges from 42 to 56 days (mean 49.50 days $\pm 1.50 \mathrm{SE}$ ) during summer and 77 to 95.5 days (mean 86.05 days $\pm 1.73 \mathrm{SE}$ ) during autumn (Table 1). Data on the feeding potential of larvae of Episyrphus balteatus showed that a larva consumes from 350 to 440 aphids (mean 415.50 aphids \pm 8.21 SE) during summer and from 455 to 640 aphids (mean 549.50 aphids $\pm 18.65 \mathrm{SE}$ ) during autumn (Table 1) . After data analysis, using t- test it is reported that since the $p$ value for both durations and feeding potential of larvae of Episyrphus balteatus is less than 0.05 level of significance, which is statistically significant. Hence null hypothesis $\left(\mathrm{H}_{\mathrm{o}}\right)$ is rejected and it is concluded there is significant difference between the total number of aphids consumed during larval period, as well as total life span of Episyrphus balteatus in summer and autumn period. 
Biology and feeding potential Episyrphus balteatus De Geer (Diptera: Syrphidae)

Table 1. Duration of different developmental stages* of Episyrphus balteatus De Geer a syrphid predators of green apple aphid, Aphis pomi De Geer on apple host.

\begin{tabular}{|c|c|c|c|c|c|c|c|}
\hline $\begin{array}{l}\text { Name of } \\
\text { species }\end{array}$ & Season & Egg & Larva & Pupa & Adult & Total life & $\begin{array}{l}\text { Aphids } \\
\text { Consumed }\end{array}$ \\
\hline $\begin{array}{l}\text { Episyrphus } \\
\text { balteatus }\end{array}$ & \multirow[t]{3}{*}{ Summer } & 2.00 & 7.90 & 8.50 & 31.10 & 49.50 & 415.50 \\
\hline \multirow[t]{5}{*}{ De Geer } & & \pm 0.00 & \pm 0.27 & \pm 0.16 & \pm 1.41 & \pm 1.50 & \pm 8.21 \\
\hline & & \multicolumn{3}{|c|}{ Skew -0.234 Kurt $-1.154^{* *}$} & \multicolumn{3}{|c|}{ Skew -2.027 Kurt $4.802^{* * *}$} \\
\hline & \multirow[t]{3}{*}{ Autumn } & 2.55 & 15.00 & 15.30 & 53.20 & 86.05 & 549.50 \\
\hline & & \pm 0.13 & \pm 0.51 & \pm 0.55 & \pm 1.51 & \pm 1.73 & \pm 18.65 \\
\hline & & \multicolumn{3}{|c|}{ Skew -0.101 Kurt -0.197 ${ }^{* *}$} & \multicolumn{3}{|c|}{ Skew -0.139 Kurt $-1.03^{* * *}$} \\
\hline
\end{tabular}

* Data for 10 individuals, \pm standard error about the mean.

** Skewness and Kurtosis of Duration of different developmental stages of Episyrphus balteatus De Geer

$* *$ Skewness and Kurtosis of total number of aphid consumed during summer and autumn season.
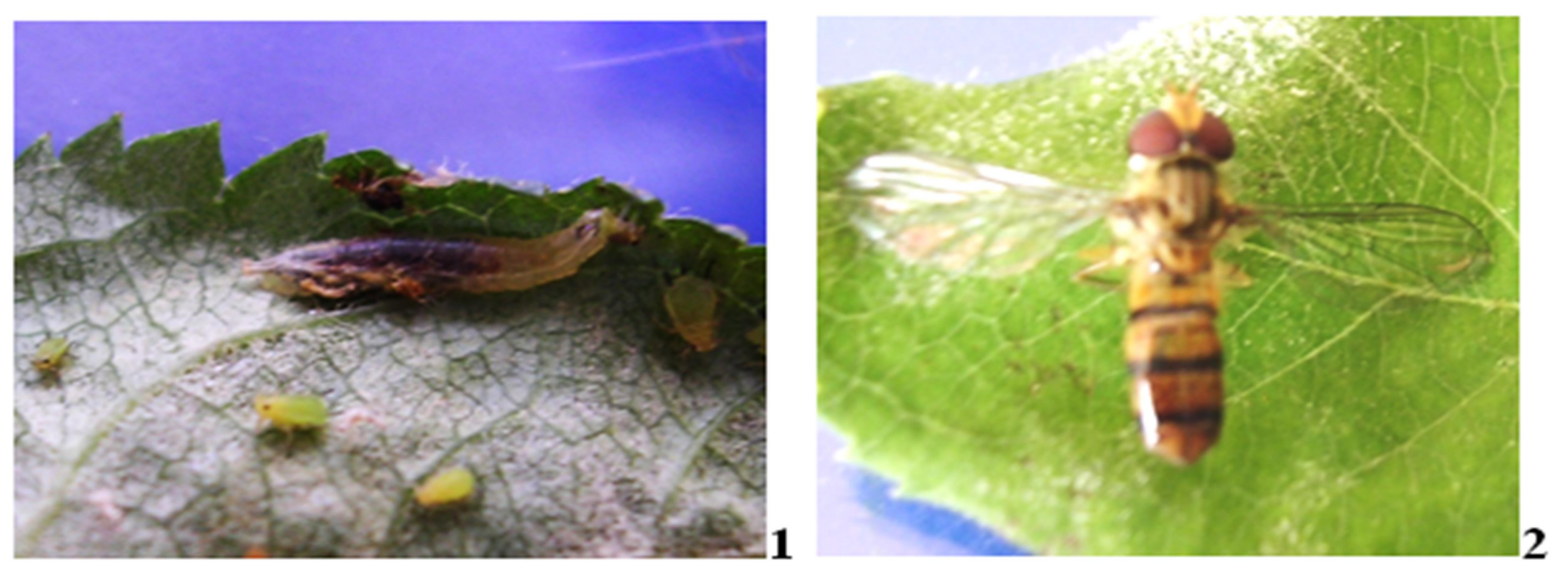

Figure: 1 \& 2. Larva and adult fly of Episyrphus balteatus De Geer.

Initial larval instar of this species was poor feeder and their capacity of feeding increased during subsequent instar stages. The larvae become voracious feeder in last instar stage consuming about hundred aphids in a day. In this way, larvae of syrphid fly check the increased infestation of green apple aphids and save the apple nursery plants from serious damage. The larvae of Episyrphus balteatus De Geer consumed on an average 415.50 aphids in summer and 549.50 aphids in autumn (Table 1). Earlier, Roy and Basu (1977) reported the feeding potential of larvae of Syrphus balteatus and Syrphus confrater which consume on an average of 510 and 708 aphids of Lipaphis erysimi respectively. The larvae of Episyrphus balteatus consumed more aphids during autumn as compared to summer because the life cycle of this species is longer during autumn as compared to summer. In the present investigations, it was observed that the larvae of this species start feeding on green apple aphids just after hatching from egg. Syrphids have been recognised as important predators of aphids as is evident from several previous studies (Campbell and Davidson, 1924; Ghosh, 1974; Ghorpade, 1981). Bhatia and Shaffi (1932) reported that the fly, Syrphus balteatus (De Geer) is one of the commonest species of the genus Syrphus and has been reported from all over India. These workers further reported that the flies of this species are seen in sufficient number in the field from January to March and are also available during most of the part of the year. 


\section{Kumari Meena}

\section{Conclusion}

Present studies indicate that larvae of this species of syrphid flies are very effective predators of green apple aphid Aphis pomi De Geer in Himachal Pradesh state of India and should be reared in large scale for use in biological control of this aphid pest of apple nursery and young plants.

\section{Acknowledgement}

Author wish to thank Dr. K.C. Sharma, YPS University of Horticulture and Forestry, Nauni for the identification/authentication for syrphid flies. I also express my deep sense of gratitude towards Dr. Sushma Bhardwaj, Regional Fruit Research Station Mashobra for all her help ,cooperation during my visits to apple nurseries in Mashobra. I give special thanks to Dr. Dinesh Singh and Sh. Heera Singh Department of commerce, Govt. College of Kullu, Himachal Pradesh for their help with data processing. I wish specially thank to Dr. Ashowk Sharma for his help and all round cooperation.

\section{References}

Banks, C. J. 1952. The natural enemies of aphids. Rep. Rothamsted Exp. Stn.,: 116-177.
Bhatia H. L and Saffi ,M. 1932. Life histories of some Indian Syrphidae. Indian J. Agri. Sci., 2: 543-569.

Carrol, D. P., Hoyt, S. 1984. Natural enemies and their effects on apple aphid, Aphis pomi De Geer (Homoptera: Aphididae), colonies on young apple trees in central Washington. Environ. Entomol., 13: 469-481.

Campbell, R.E, Davidson, W. M. 1924. Notes on aphidophagous syrphidae of southern California. Bull. Southern Calif. Acad. Sci., 24: 1-14.

Gautam, D. C., Kumari, M. 2004. Biology of green apple aphid (Aphis pomi De Geer) on apple host. Indian Journal of Horticulture, 61: 229-231.

Ghorpade, K. D, 1981. Insect prey of Syrphidae (Diptera) from India and neighbouring countries: a review and bibliography. Tropical Pest Management, 27: 62-82.

Ghosh , A. K. 1974. Aphids (Homoptera: Insect) of economic importance in India. Indian Agriculture, 18: 81-214.

Hamilton, G. C., Swift, F. C., Marini, R. 1986. Effect of Aphis pomi (Homoptera: Aphdidae) density on apples. J. Econ. Entomol., 79: 471-478.

Oatman, E. R., Legner, E. F. 1961. Bionomics of the apple aphid, Aphis pomi, on young non-bearing apple trees. $\boldsymbol{J}$. Econ. Entomol., 54: 1034-1037.

Roy, P. Basu ,S. K. 1977.Bionomics of aphidophagous syrphid flies. Indian J. Entomol., 39: 165-174. 